\title{
Expression of osteoprotegerin, receptor activator of nuclear factor kappa-B ligand, tumor necrosis factor-related apoptosis-inducing ligand, stromal cell-derived factor- 1 and their receptors in epithelial metastatic breast cancer cell lines
}

Vivian Labovsky ${ }^{1,2}$, Valeria B Fernández Vallone ${ }^{1,2}$, Leandro M Martinez ${ }^{1,3}$, Julian Otaegui ${ }^{1}$ and Norma A Chasseing ${ }^{1,2,4^{*}}$

\begin{abstract}
Background: While breast cancer (BC) is the major cause of death among women worldwide, there is no guarantee of better patient survival because many of these patients develop primarily metastases, despite efforts to detect it in its early stages. Bone metastasis is a common complication that occurs in 65-80 \% of patients with disseminated disease, but the molecular basis underlying dormancy, dissemination and establishment of metastasis is not understood. Our objective has been to evaluate simultaneously osteoprotegerin (OPG), receptor activator of nuclear factor kappa B ligand (RANKL), tumor necrosis factor-related apoptosis-inducing ligand (TRAIL), stromal cell-derived factor-1 (SDF-1), and their receptors (R) in 2 human BC cell lines, MDA-MB-231 and MCF-7.

Methods: OPG, RANKL, TRAIL and SDF-1 expression and release, in addition to the expression of their receptors has been investigated using immunofluorescence, immunocytochemistry and ELISA analyses.

Results: MCF-7 cells released higher levels of OPG in conditioned media (CM) than MDA-MB-231 cells; $100 \%$ of both types of cell expressed OPG, RANKL, TRAIL and SDF-1. Moreover, $100 \%$ in both lines expressed membrane RANKL and RANK, whereas only $50 \%$ expressed CXCR4. Furthermore, $100 \%$ expressed TRAIL-R1 and R4, 30-50\% TRAIL-R2, and 40-55\% TRAIL-R3.
\end{abstract}

Conclusions: MCF-7 and MDA-MB-231 cells not only released OPG, but expressed RANKL, TRAIL and SDF-1. The majority of the cells also expressed RANK, CXCR4 and TRAIL-R. Since these ligands and their receptors are implicated in the regulation of proliferation, survival, migration and future bone metastasis during breast tumor progression, assessment of these molecules in tumor biopsies of BC patients could be useful in identifying patients with more aggressive tumors that are also at risk of bone metastasis, which may thus improve the available options for therapeutic intervention.

Keywords: OPG, RANKL, TRAIL, SDF-1, Breast cancer cells

\footnotetext{
* Correspondence: alejachase@gmail.com

'Laboratorio de Inmuno-Hematología, Instituto de Biología y Medicina

Experimental (IBYME), Buenos Aires, Argentina

${ }^{2}$ Consejo Nacional de Investigaciones, Científicas y Técnicas (CONICET),

Buenos Aires, Argentina

Full list of author information is available at the end of the article
} 


\section{Background}

Breast cancer (BC) remains the most common cancer among women in both the United States and worldwide [1-4]. Many individuals with BC develop metastases to secondary organs, e.g. bone marrow (BM) and bone [1$3,5]$.

The development and spread of tumors are due to the ability of malignant cells to avoid detection and removal by the immune system, grow in non-native sites and avoid programmed or induced cell death [6]. Indeed, $70 \%$ of patients with advanced BC develop metastases in $\mathrm{BM}$ and bone (osteolytic lesions) within one year after diagnosis of the primary tumor [2,7]. However, the factors favoring $\mathrm{BC}$ growth in both the primary tumor and metastatic sites are unclear, making the mechanisms involved by which primary tumor cells metastasize to secondary organs a major clinical challenge.

Focusing on bone metastasis, there is a vicious cycle between bone resorption and tumor proliferation in which osteoprotegerin (OPG), receptor (R) activator of nuclear factor kappa B (RANK), RANK ligand (RANKL) and tumor necrosis factor (TNF)-related apoptosisinducing ligand (TRAIL) play a pivotal role [8-10].

OPG, a member of the TNF-R superfamily, binds RANKL, blocking its interaction with RANK and thereby preventing osteoclast differentiation, activation and survival $[7,11]$.

The BC cell line MDA-MB-231 produces sufficient OPG to bind TRAIL, which upregulates RANKL expression [6]. Briefly, OPG secreted by this BC cell line, acting as a paracrine factor, could affect RANKL production, enhancing osteolysis and the perpetuation of this vicious cycle [6]. In human malignancies that metastasize to bone, dysregulation of the RANK/RANKL/OPG pathway can increase the RANKL: OPG ratio, which would favor excessive osteolysis [12-15]. In a mouse model of bone metastasis, the RANKL protein levels in MDA-MB-231 tumor-bearing bones were significantly higher than in tumor-free bones [16]. The resulting tumor-induced osteoclastogenesis and osteolysis were inhibited by recombinant OPG in a dose-dependent manner. Inhibition of RANKL blocked tumor-induced osteolysis and skeletal tumor progression and improved survival in murine models of BC bone metastasis [17]. RANK allows cells to proliferate, migrate and invade other tissues, specifically $\mathrm{BM}$ and bone. Additionally, RANK is expressed in many different epithelial tissues and epithelial tumor cells, and in vitro stimulation of human $\mathrm{BC}$ cell lines (MDAMB-231, MCF-7 and Hs578T) with RANKL results in concentration-dependent cell migration, which is blocked by recombinant OPG [7]. Moreover, OPG also binds to TRAIL and inhibits its pro-apoptotic effect [18].

TRAIL induces apoptosis through the death receptors DR4/R1 and DR5/R2 that are expressed on the surface of target cells [19-22]. In preclinical models, TRAIL has anticancer activity [23]. Unfortunately, $>50 \%$ of the tumor cells are resistant to TRAIL. In some cases, TRAIL resistance is caused by a high and simultaneous expression of other TRAIL-R-like decoy $R$ (DcR1/R3 and DcR2/R4) and soluble OPG [24]. However, the presence of decoy $\mathrm{R}$ cannot explain the lack of response of many cancer cells to antibodies specifically targeting DR4, DR5 or recombinant TRAIL. TRAIL resistance in $\mathrm{BC}$ cells has been associated with constitutive endocytosis of death receptors 4 and 5 (R1 and R2) [24]. Thus, it is important to develop new strategies to overcome this type of resistance in tumor cells. Interestingly, some groups have described the ability of subtoxic concentrations of chemotherapeutic drugs to sensitize tumor cells resistant to TRAIL [23,25,26]. Also the anticancer efficacy of TRAIL against BC cells is known to be retained in the bone microenvironment, even in the present of biologically active OPG at a supraphysiologic concentration [18].

Finally, SDF-1, a member of the CXC subfamily of chemokines that mediates several cellular functions (adhesion, survival, proliferation and migration) via interaction with CXCR4, is found at high levels in organs to which $\mathrm{BC}$ frequently metastasizes, which include lymph nodes, lungs, liver and bone [27]. CXCR4 is expressed by fibroblasts, endothelial, hematopoietic cells and stromal cells, in different types of cancer cells, such as BC cells, and in numerous types of embryonic and adult stem cells (SCs), which can be chemoattracted by its ligand, SDF-1 [2831]. CXCR4 expression in tumor cells of several types of carcinomas is correlated with a poor prognosis, e.g. breast and prostate tumors [27,28,32-34]. Furthermore, CXCR4 overexpression in BC cells is correlated with a worse prognosis and decreased patient survival, irrespective of the status of the estrogen-receptor (ER) [35]. Knockdown of CXCR4 expression using small interfering RNA in BC cells decreases in vitro cell survival, invasion and proliferation and abrogates in vivo tumor growth $[28,34,36,37]$. In addition SDF-1/CXCR4 in malignant tumors could provide paracrine signals that promote malignant progression, i.e. invasion and cell proliferation that leads to metastasis [28,38]. In contrast, a high level of SDF-1 expression (in a cytoplasmicdominant pattern) in $\mathrm{BC}$ cells seems to be a significant indicator of a better clinicopathological outcome, particularly in patients with ER-positive, HER-2negative, and lower grade tumors [29]. Moreover, Corcoran et al. [39] detected membrane-bound SDF-1 in MCF-7 and T47D BC cell lines, but not in the MDAMB-231 cell line, which could be relevant in the interaction with CXCR4-expressing mesenchymal stem cells $[39,40]$. They also suggested that SDF-1 might occupy CXCR4 in BC cells through autocrine binding, possibly 
resulting in these cells losing their efficiency in metastasizing to organs with a high concentration of SDF-1. They proposed that CXCR4 antagonists might be ideal for patients who are diagnosed early without lymph node involvement [41]. This type of therapy could be prudent in preventing low numbers of $\mathrm{BC}$ cells from entering $\mathrm{BM}$ and bone.

A better understanding of the interactions between complex tumor cells and host cells focusing on the bone microenvironment, along with a better understanding of the autocrine and paracrine effects of the factors secreted from tumor cells and bone matrix may facilitate the development of effective strategies that inhibit metastatic disease progression. It is also important to study the early events involved in BC cell entry into the BM.

Therefore, since these ligands and their receptors are molecules involved in the proliferation, survival, migration and possible future $\mathrm{BM} /$ bone metastasis of $\mathrm{BC}$ cells, studying their simultaneous in vitro expression in human $\mathrm{BC}$ cell lines, such as the ER-negative MDA-MB-231 (highly invasive and metastatic cells) and ER-positive MCF-7 (weakly invasive and metastatic cells), offers an approach to a better understanding of their involvement in the evolution of BC. Much of the available data about the expression of these factors and receptors in $\mathrm{BC}$ cells is to some degree contradictory. Hence, it is important to study the expression and release of these ligands and the expression of their receptors with time (after 1-4 days) and under conditions of arrest and post-stimulation with $10 \%$ fetal bovine serum (FBS) for $48 \mathrm{~h}$.

\section{Results}

Analysis of the levels of OPG, RANKL, TRAIL and SDF-1 in conditioned media from MDA-MB-231 and MCF-7 cells by ELISA

Since increasing the cell concentration of either $\mathrm{BC}$ lines $\left(18 \times 10^{3}\right.$ or $50 \times 10^{3}$ cells $\left./ \mathrm{cm}^{2}\right)$ did not change the levels of OPG, RANKL, TRAIL and SDF-1 under traditional culture conditions (data not shown), our results represent only the levels using $18 \times 10^{3} \mathrm{cell} / \mathrm{cm}^{2}$ in both culture conditions.

The level of OPG in CM of the MDA-MB-231 cells increased progressively over time, with a maximum at day 4 (D4), whereas in the CM of the MCF-7 cells, the highest level happened after $48 \mathrm{~h}$ (day 2, D2) (Figure 1A). MCF-7 cell line released higher levels of OPG than the MDAMB-231 line at D2 ( $<<0.05$, Bonferroni post hoc test).

Both cell lines expressed different levels of OPG under conditions of arrest and post-stimulation (Figure 1B). However, the levels of OPG produced after stimulation were higher in the MCF-7 cells compared to the MDAMB-231 cells $(\mathrm{p}=0.0130$, unpaired t-test with Welch's correction).
Regardless of the culture conditions and the type of BC cell line used, the levels of RANKL, TRAIL and SDF-1 were below the ELISA detection limit $(<31.25 \mathrm{pg} / \mathrm{ml})$.

Analysis of the expression of OPG, RANKL and TRAIL in MDA-MB-231 and MCF-7 cells by immunofluorescence In vitro traditional culture condition results in both $\mathrm{BC}$ cell lines expressing similar levels of OPG, RANKL and TRAIL (Figure 2A). MDA-MB-231 and MCF-7 cells displayed a decrease in OPG expression at day 2. OPG, RANKL and TRAIL were expressed in $100 \%$ of the BC cells. No immunostaining was observed when the MDAMB-231 and MCF-7 cells were incubated either without a primary antibody $(\mathrm{Ab})$ or with an irrelevant $\mathrm{Ab}$ as a negative isotype control. Figure $2 \mathrm{~B}$ shows only the results obtained from the two $\mathrm{BC}$ cell lines grown until D4 as representative results.

RANKL and TRAIL were also expressed in $100 \%$ of the MDA-MB-231 and MCF-7 cells, under conditions of both arrest and post-stimulation (Figure 3A). Independently of the cell type used, this expression/cell was higher post-stimulation. Regarding the production of OPG its expression/cell was minimal under arrest conditions but increased post stimulation. No immunofluorescence was observed when the primary Ab was omitted or other negative controls were used (Figure 3B).

\section{Evaluation of the expression of membrane RANKL in} MDA-MB-231 and MCF-7 cells by immunocytochemistry Independently of the culture conditions or the cell concentration plated, RANKL was undetectable in the CM of the MDA-MB-231 and MCF-7 cells. Membrane expression of RANKL (mRANKL) should be evaluated as its functions could be assessed not only as soluble factor but also as a membrane protein via cell-to-cell contact through RANK. Immunocytochemistry analysis of the MDA-MB-231 and MCF-7 cells showed positive and similar expression of membrane and cytoplasmatic RANKL (cRANKL) in $100 \%$ of cells under both culture conditions. Figure $4 \mathrm{~A}$ and $\mathrm{B}$ show the results from both $\mathrm{BC}$ cell lines grown under traditional culture conditions for $24 \mathrm{~h}$ (day 1, D1) and arrest and poststimulation culture conditions. Positive expression for AE1AE3 was used as a positive control. No immunostaining was observed in any of the cells when they were incubated without specific primary Abs or with other negative control.

\section{Evaluation of the expression of RANK, SDF-1 and CXCR4 in MDA-MB-231 and MCF-7 cells by immunocytochemistry}

Immunocytochemistry analysis of membrane and cytoplasmic RANK (mRANK and cRANK) displayed $100 \%$ positive expression in MDA-MB-231 and MCF-7 cells 


\section{A. Traditional culture conditions}
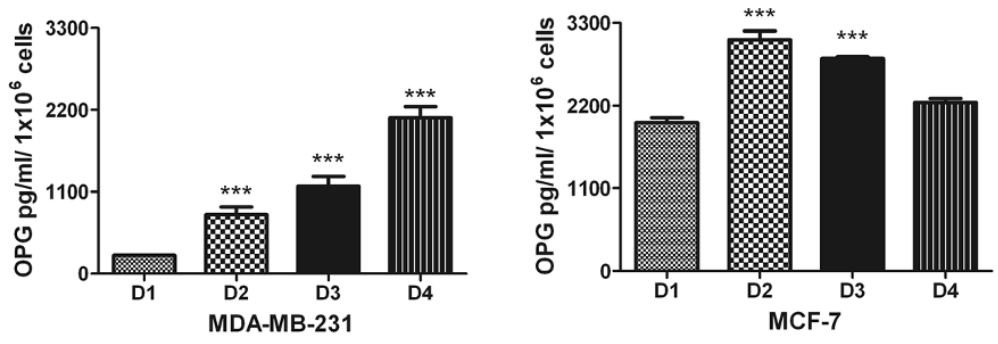

B. Arrest and post-stimulation culture conditions

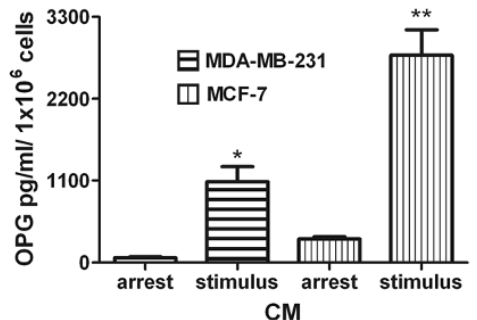

Figure 1 Release of OPG from BC cell lines under two different culture conditions detected by ELISA. (A) Traditional culture conditions. Conditioned media (CM) from the cell cultures at 24, 48, 72 and $96 \mathrm{~h}$ [Days (D): D1-D4] from both BC cell lines were used to evaluate the levels of OPG by ELISA. The values of OPG are expressed as $\bar{X} \mathrm{pg} / \mathrm{ml} / 1 \times 10^{6}$ cells + standard error (SE). Statistical significance: One-way analysis of variance (ANOVA) followed by a Bonferroni post hoc test. Asterisks (*) indicate a significant difference $(p<0.05)$ compared to D1 for each cell line. (B) Arrest and post-stimulation culture conditions. CM obtained under arrest at $48 \mathrm{~h}$ and subsequent stimulation with $10 \% \mathrm{SBF}$ for $48 \mathrm{~h}$ from both BC cell lines were used to evaluate the levels of OPG by ELISA. The OPG values are expressed as $\bar{X} \mathrm{pg} / \mathrm{ml} / 1 \times 10^{6}$ cells + standard error (SE). Statistical significance: Unpaired t-test with Welch's correction. Asterisks $\left(^{*}\right)$ indicate a significant difference $\left(p=0.0158,{ }^{*}\right.$ and $p=0.0056$, **) between OPG production during arrest and after stimulation in the MDA-MB-231 and MCF-7 cell lines.

under both culture conditions. Figure $5 \mathrm{~A}$ and $\mathrm{B}$ show the results from the two $\mathrm{BC}$ cell lines grown under arrest and post-stimulation culture conditions.

One hundred of BC cells expressed SDF-1 under both culture conditions. In contrast, $50 \%$ of these cells showed a weak CXCR4 expression under both culture conditions. But, there was an increase of expression after stimulation and on days 1 to 4 under traditional culture conditions. Figure $5 \mathrm{~A}$ and $\mathrm{B}$ show the results obtained for $\mathrm{BC}$ cells grown under arrest and post-stimulation culture conditions. No staining was observed in the negative controls (Figure 5B).

\section{Evaluation of the expression of TRAIL and its receptor in} MDA-MB-231 and MCF-7 cells by immunocytochemistry Figures $6 \mathrm{~A}$ and $\mathrm{B}$ show the results obtained from the two BC cell lines grown under arrest and poststimulation culture conditions. Immunocytochemistry staining of MDA-MB-231 and MCF-7 cells exhibited positive and similar expression patterns of TRAIL-R1 and R4 in $100 \%$ of cells in cultures of both lines (Figure 6A). However, TRAIL-R2 and TRAIL-R3 were weakly expressed. TRAIL-R2 expression was stronger in MDA-MB-231 cells than in MCF-7 cells, with 30 to $50 \%$ of cells showing staining in cultures of both cell lines. TRAIL-R3 was expressed with the same intensity in culture, showing 40 to $55 \%$ positive cells.

Positive expression of AE1AE3 (used as a positive control) was observed. In cultures where the primary Ab was omitted or other negative controls were used, negligible staining was observed (Figure 6B).

\section{Discussion}

Bone metastasis is a common event in advanced breast cancer. Once tumors metastasize to bone, they are usually incurable, with a five-year survival rate of $20 \%$ [42].

MCF-7 and MDA-MB-231 cell lines, extracted from pleura, are metastatic and belonged to $\mathrm{BC}$ patients at an advanced clinical stage. In addition, Corcoran et al. found a low invasivity preference of MCF-7 and T47D cells to BM, but MDA-MB-231 cells are highly metastatic to lung and BM [39]. Based on these background findings, the results presented in this work may contribute to in vitro analysis of the expression and release of factors involved in the BM/bone metastasis of BC cells, such as OPG, RANKL, TRAIL, SDF-1 and their receptors.

OPG and its two ligands, TRAIL and RANKL, are expressed at different levels in normal breast tissue and breast tumor tissue [43]. However, it is not fully 

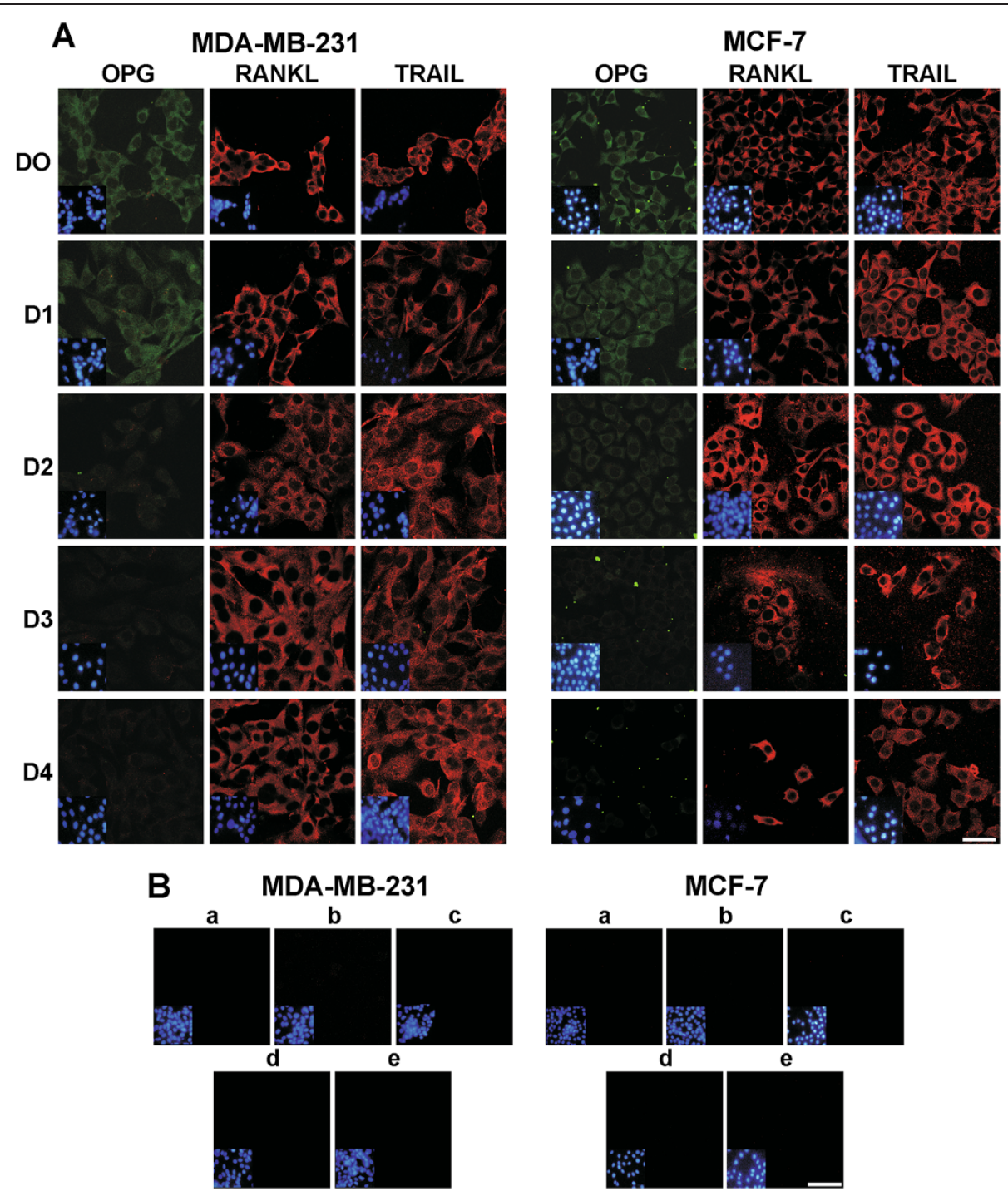

Figure 2 Immunofluorescence detection of OPG, RANKL and TRAIL in both BC cell lines grown under Traditional culture conditions. (A) Immunofluorescence staining for OPG, RANKL and TRAIL was positive in both BC cell lines. D: day; D0: cells at time zero; D1, D2, D3 and D4: cell lines grown for 24, 48, 72 and 96 h, respectively. The insert shows nuclear DNA stained with DAPI. The scale bar represents $30 \mu \mathrm{m}$. (B) Both BC cell lines were grown until D4 ( $96 \mathrm{~h}$ ) and incubated either without a primary Ab and with the followings Abs: a) Cy3-labeled goat anti-mouse IgG, b) FITC-labeled goat anti-rabbit IgG, c) an irrelevant Ab as a negative isotype control, such as IgG1, d) mouse lgs and e) rabbit Igs. In controls $\mathbf{c}$ and $\mathbf{d}$, the cell lines were stained with a Cy3-labeled goat anti-mouse IgG Ab, and in control e, they were stained using a FITC-labeled goat anti-rabbit lgG Ab. The insert shows nuclear DNA stained with DAPI. The scale bar represents $30 \mu \mathrm{m}$.

understood their role during the development of human $\mathrm{BC}$, and which types of cells produce them within the tumor microenvironment. Therefore, OPG could exert either anti- or pro-tumoral effects in cells based on whether it binds RANKL or TRAIL, which depends on the relative concentrations of the two cytokines in $\mathrm{BC}$ tissue during tumor progression $[8,11,44,45]$. OPG binding to TRAIL inhibits the apoptosis of some BC cells, increasing their survival. Nevertheless, OPG binding to RANKL inhibits osteoclastogenesis and in some BC cells, decreases the ability to migrate, especially to $\mathrm{BM} / \mathrm{bone}$, due to inhibiting the interaction between RANKL and
RANK $[7,46]$. RANKL is abundantly expressed in BM/ bone [7]. Recently, Santini et al. demonstrated that RANK expression in primary tumors from $B C$ patients is a predictive marker of both the occurrence of $\mathrm{BM} / \mathrm{bone}$ metastasis and of shorter skeletal disease-free survival [47].

TRAIL acts as an apoptotic factor in osteoclasts and in BC cells (ER negative) $[48,49]$. In primary breast tumor and metastatic sites, TRAIL is released by BC cells, activated fibroblasts, macrophages, lymphocytes and post- TNF- $\alpha /$ interferon- $\alpha /-\gamma$ stimulated mesenchymal stem cells (MSCs) $[8,43,45,50]$. 

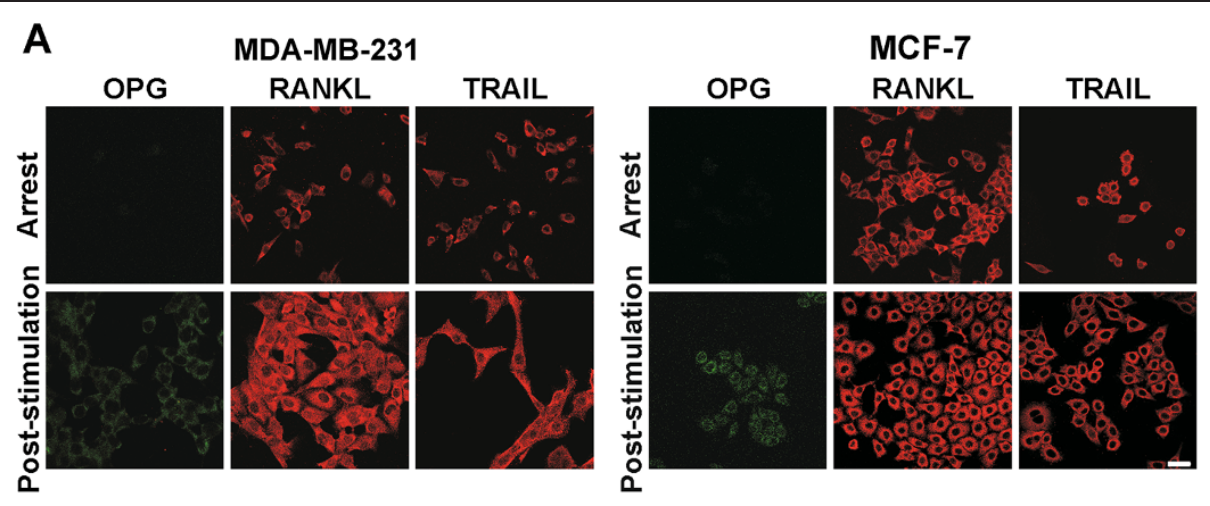

B

MDA-MB-231
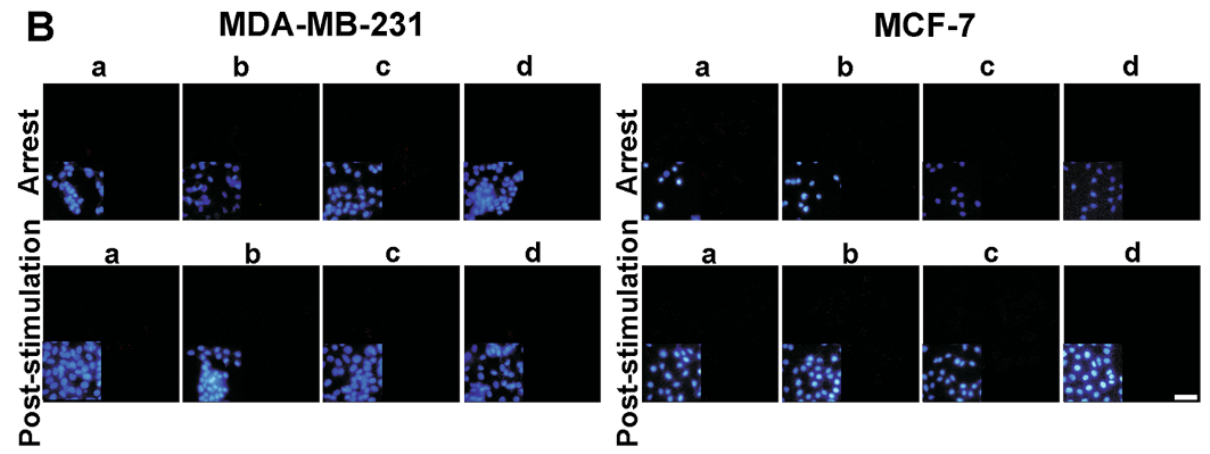

Figure 3 Expression of OPG, RANKL and TRAIL in both BC cell lines. (A) Immunofluorescence staining for OPG, RANKL and TRAIL in both BC cell lines grown under arrest and post-stimulation culture conditions. The scale bar represents $50 \mu \mathrm{m}$. (B) The MDA-MB-231 and MCF-7 cell lines were grown under arrest and post-stimulation culture conditions and incubated either without a primary Ab and with the followings Abs: a) Cy3labeled goat anti-mouse $\operatorname{lgG}, \mathbf{b}$ ) FITC-labeled goat anti-rabbit lgG, c) an irrelevant Ab as a negative isotype control, such as lgG1, and d) rabbit lgs. In control $\mathbf{c}$, the cell lines were stained with a Cy3-labeled goat anti-mouse IgG Ab, and in control $\mathbf{d}$, they were stained with a FITC-labeled goat anti-rabbit lgG Ab. The insert shows nuclear DNA stained with DAPI. The scale bar represents $30 \mu \mathrm{m}$.

The function of OPG released by a tumor after migration to $\mathrm{BM} /$ bone is not fully understood because of the low levels of secretion compared to those produced by MSCs from BM and osteoblasts [44]. Accordingly, we found that both the MDA-MB-231 and MCF-7 cell lines, independent from being ER positive or negative, expressed and released OPG. The OPG levels detected in the CM from both culture conditions were lower than the levels found in previous studies from our laboratory working with the CM of MSCs from the BM of healthy volunteers and untreated advanced $\mathrm{BC}$ patients free of $\mathrm{BM}$ and bone metastases [51,52]. Therefore, we can conclude that when $\mathrm{BC}$ cells first enter $\mathrm{BM} / \mathrm{bone}$, they release OPG that may be important via binding to TRAIL secreted by osteoclasts or other cells of the stromal microenvironment. Moreover, $\mathrm{BC}$ cells can play a role in the distance releasing of OPG or other factors to the circulation, hence exerting its action in BM/bone. Thus, BC cells may inhibit their own and osteoclasts apoptosis and further contribute to the spontaneous osteoclastogenesis observed by our group in the peripheral blood and $\mathrm{BM}$ of untreated advanced $\mathrm{BC}$ patients prior to bone metastasis [51,52]. However, this last interaction cannot significantly modify the production of osteoclasts because it is triggered by the hematopoietic microenvironment, especially MSCs and osteoblasts, prior to the arrival of tumor cells and of the development of bone metastasis $[51,52]$.

Furthermore, OPG can be regulated by sulfated proteoglycans (PGs), which inhibit the adherence and resorptive activity of osteoclasts $[8,53]$. The capture of OPG in the extracellular matrix of $\mathrm{BM} /$ bone favors bone osteolysis, further contributing to bone disorders leading to the appearance of metastasis. The PG-OPG interaction blocks OPG activity via preventing binding to TRAIL and RANKL as well as decreasing its half-life $[8,53,54]$. Therefore, the OPG anti- or pro-tumor activity in the $\mathrm{BM} /$ bone microenvironment is determined by the relative concentrations of each of its ligands (RANKL, TRAIL and sulfated PG) [8]. In contrast, recent data indicated that the role of OPG released by BC cells injected intratibially into normal mice preserved the integrity of bone and prevented $\mathrm{BC}$-induced bone destruction because its principal role is binding RANKL in vivo [18]. Finally, OPG increases endothelial cell survival and induces angiogenesis, favoring further development of 

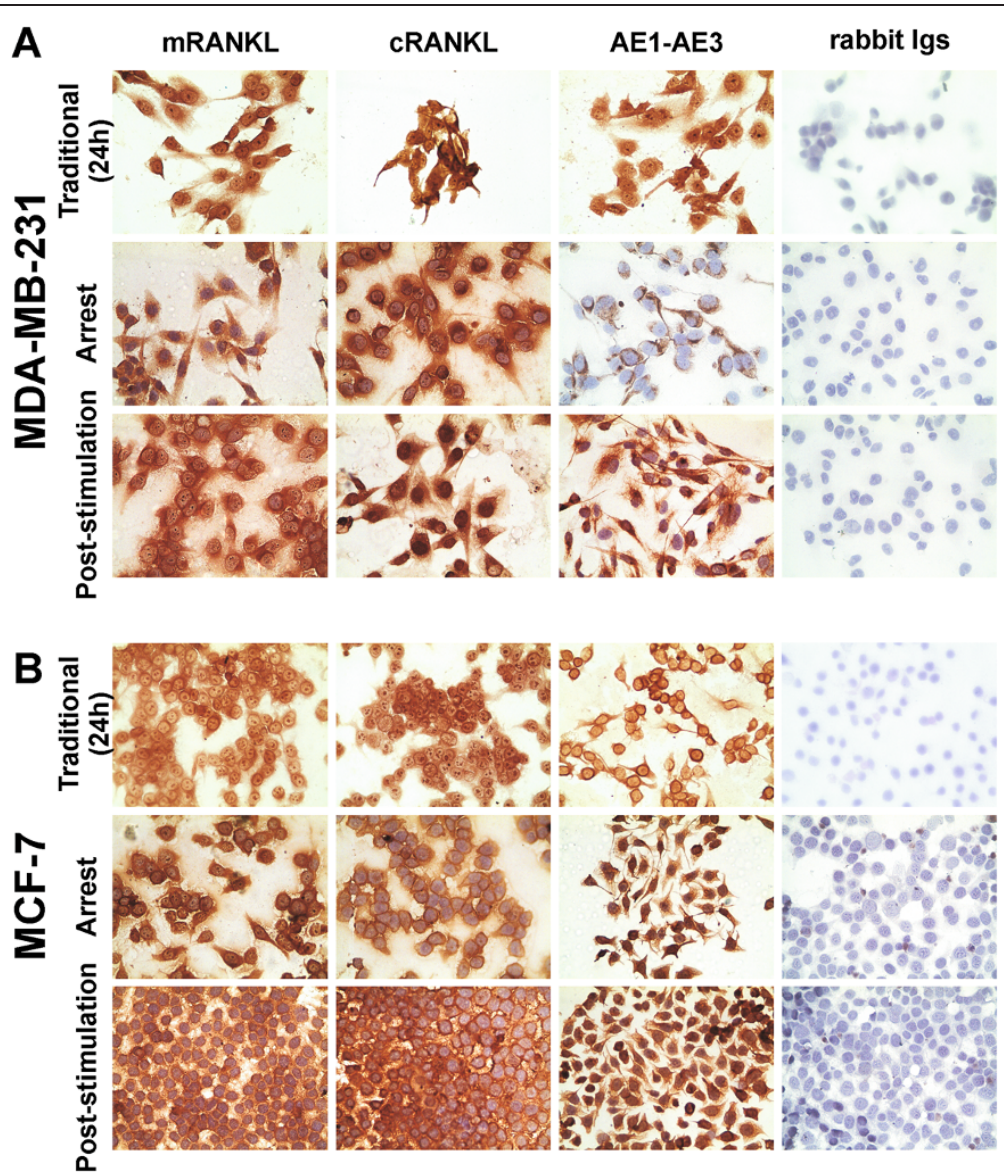

Figure 4 Expression of membrane RANKL on BC cell lines under the two different culture conditions. (A) Immunocytochemistry staining for mRANKL in the MDA-MB-231 cell line under both culture conditions (x 400 magnification). (B) Immunocytochemistry staining for mRANKL in the MCF-7 cell line under both culture conditions ( $x$ 400). Positive controls were performed in both BC cell lines incubated with anti-RANKL (cytoplasmatic RANKL =CRANKL, evaluated previously) and anti-AE1AE3 (a pan-cytokeratin epithelial marker). No staining was observed in both BC cell lines incubated with an irrelevant rabbit Ig Ab as a negative isotype control. Nuclei were counterstained with hematoxylin (purple).

primary tumors and the appearance of metastasis, including to BM and bone [11].

As stated, BC cells from the MCF-7 and MDA-MB231 cell lines released OPG, independent of the culture conditions used. MCF-7 line released was greater and faster as a function of time. These results are consistent with those of other authors who found that the production of OPG is higher in ER-positive cells in primary tumors than in ER-negative cells $[43,55]$. In addition, Holen et al. have observed that after culturing the MDAMB-231 line for $72 \mathrm{~h}$, the cells produced $768 \pm 64 \mathrm{pg} / \mathrm{ml}$ of OPG [55], which is very similar to the levels we obtained for this line on the third day $(614.20 \pm 161 \mathrm{pg} / \mathrm{ml}$, traditional culture conditions). In contrast, other authors have detected OPG levels of approximately $1,750 \mathrm{pg} / \mathrm{ml}$ in MDA-MB-436 cells and comparable levels in MDA-MB231, but they have not observed OPG in CM from MCF-7 cells [44].
We detected intracytoplasmic expression of OPG, RANKL and TRAIL in both cell lines, observing a decrease in the expression of OPG from the second day (traditional culture conditions) in both cell lines. This correlates with higher levels of OPG in the CM. Kapoor et al. observed that the expression of OPG in MDAMB-231 cells is directly correlated with the colonization and homing potential related to bone and not with metastasis to other organs [56].

Based on these findings, it appears that OPG has a multifactorial role in the development of osteolytic-type bone metastasis, as in BC. An increase in the RANKL/ OPG ratio favors the formation of osteoclasts within the bone microenvironment and is a bad prognostic factor in $\mathrm{BC}$ patients [12]. In the present study, we were not able to quantify the level of soluble RANKL in the CM of $\mathrm{BC}$ cells. Nevertheless, we found that $100 \%$ of BC cells expressed membrane RANKL under both culture 

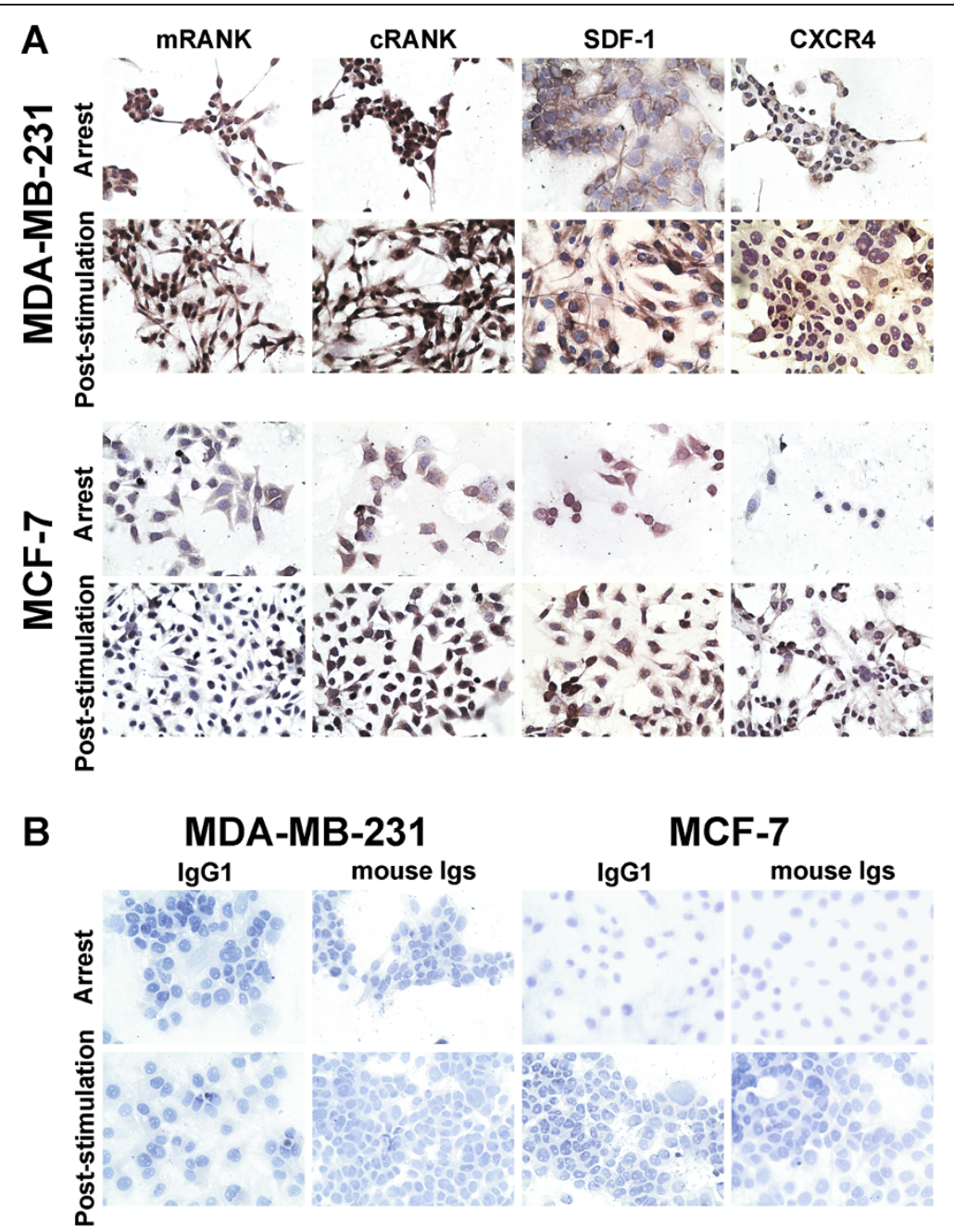

Figure 5 Expression of membrane and cytoplasmic RANK (mRANK/CRANK), SDF-1 and CXCR4 in both BC cell lines. (A)

Immunocytochemistry staining for RANK, SDF-1 and CXCR4 in MDA-MB-231 and MCF-7 cells grown under arrest and post-stimulation culture conditions ( 400 magnification). (B) The MDA-MB-231 and MCF-7 cell lines were incubated with irrelevant lgG1 and mouse lgs Abs as negative isotype controls (x 400 magnification). Nuclei were counterstained with hematoxylin (purple).

conditions, independent of the tumor cell line used, allowing these cells to proliferate, migrate and specifically invade BM and bone. Brown et al. showed that cells that metastasize to bone exhibit higher RANKL expression than cells that metastasize to other organs [57]. Therefore, $\mathrm{BC}$ cells could migrate to $\mathrm{BM} /$ bone and promote the differentiation of preosteoclasts into osteoclasts, thus further promoting the osteolytic process that leads to the emergence of bone metastasis. This suggests that the most important event for the bone metastasis establishment is the increase in osteoclast formation and bone resorption processes that finally leads to the invasion and proliferation of $\mathrm{BC}$ cells in bone.

We showed that $100 \%$ of the cells from the MDAMB-231 and MCF-7 cell lines expressed RANK and
SDF-1 under both culture conditions, despite showing no detectable levels of this last factor released into the CM. Moreover, analysis of CXCR4 expression exhibited positive weak staining in $50 \%$ of the cells from both BC cell lines under both culture conditions. These results suggest that cells expressing RANK and CXCR4 have the ability to migrate to $\mathrm{BM}$ through the action of RANKL and SDF-1 released by BM stromal cells, fibroblasts or osteoblasts [4,58-60].

Neville-Webbe et al. have shown that hormone independent TRAILS' sensitive BC cell lines cease being sensitive in the presence of recombinant OPG, thereby enhancing tumor cell survival [44]. In contrast, other authors have reported that the anti-cancer efficacy of TRAIL is retained in the presence of high, biologically active concentrations of OPG in vivo [18]. These findings 

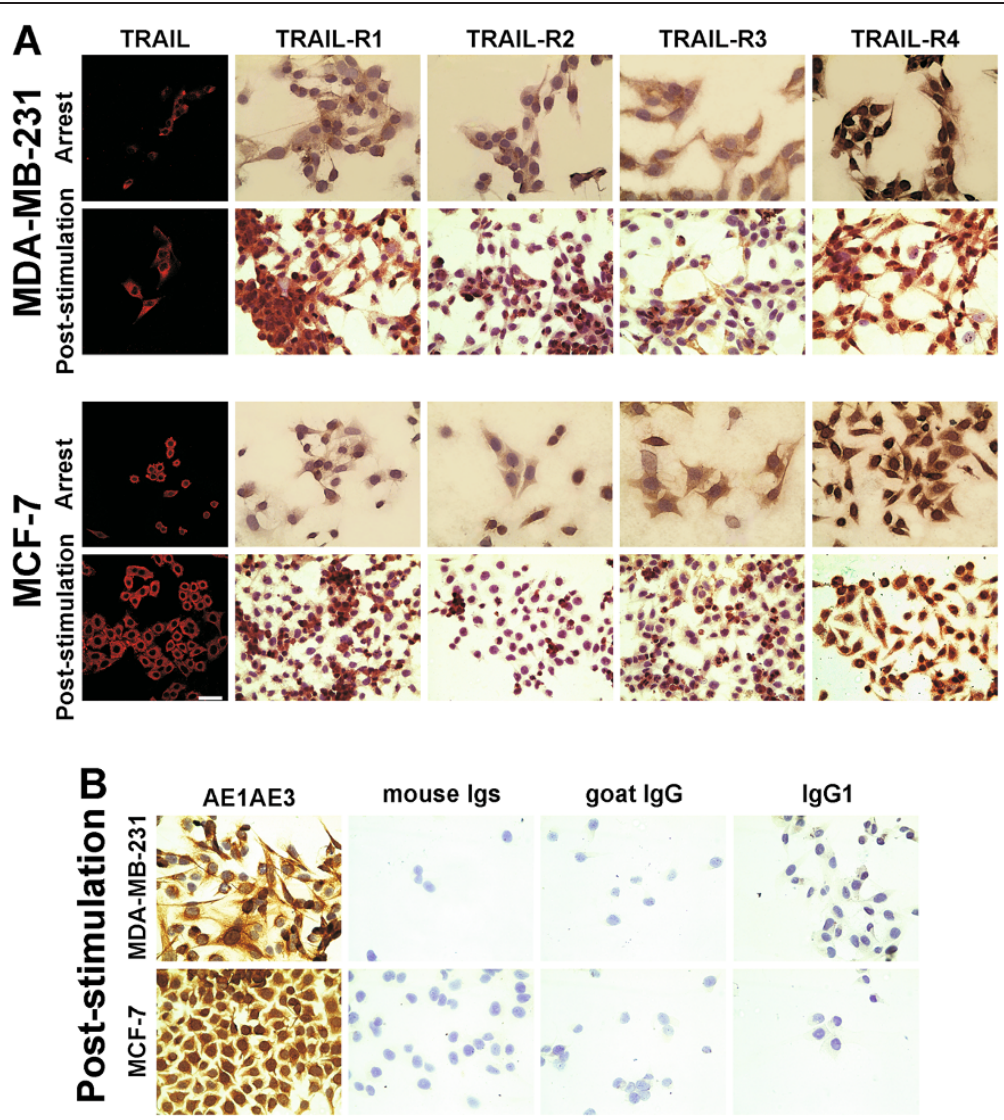

Figure 6 Expression of TRAIL, TRAIL-R1, TRAIL-R2, TRAIL-R3 and TRAIL-R4 in both BC cell lines. (A) Immunocytochemistry staining for TRAIL, TRAIL-R1, TRAIL-R2, TRAIL-R3 and TRAIL-R4 in the MDA-MB-231 and MCF-7 cell lines grown under arrest and post-stimulation culture conditions (x 400 magnification). (B) The MDA-MB-231 and MCF-7 cell lines were incubated with anti-AE1AE3 (positive control) and with irrelevant mouse lgs, goat lgG and lgG1 Abs as negative isotype controls ( $x 400$ magnification). Nuclei were counterstained with hematoxylin (purple).

showed the importance of measuring the levels of OPG, TRAIL and TRAIL-R in BC patients, particularly those that are ER negative. Further investigation of the regulation of TRAIL by OPG could aid in designing new therapeutic strategies, where the apoptotic action of TRAIL could be increased in BC cells at the early stages of the disease.

Regarding the release of TRAIL, the results of the present study showed levels below the minimum level detectable by ELISA in the CM from both tumor cell lines. It is probable that in vitro, some of the multiple factors needed for the release of TRAIL by BC cells are absent, as this situation is very different from that in vivo.

Yagita et al. have reported that the absence of total TRAIL-R1 and R2 protein on the cell surface is sufficient to account for the failure of apoptosis [21]. Thus, evaluation of expression of these receptors could serve as a potential predictive marker of TRAIL sensitivity in BC cells. Moreover, positive TRAIL-R4 expression is correlated with tumoral grade in $\mathrm{BC}$ patients with invasive ductal carcinoma [61], the expression of TRAIL-R is associated with the resistance of MCF-7 cells to the action of TRAIL and the expression of TRAIL-R3/R4 could compete with TRAIL-R1 and/or -R2 to binding TRAIL blocking apoptosis signaling [62,63]. It appeared to be important to assess TRAIL-R expression in the MDA-MB-231 and MCF-7 cell lines to consolidate the results under the two different culture conditions. Our data showed that $100 \%$ of the cells from both lines expressed TRAIL-R1 and TRAIL-R4. However, we found that only 30 to $55 \%$ of these cells weakly express TRAIL-R2 and TRAIL-R3, being stronger the TRAIL-R2 expression in MDA-MB-231 than in MCF-7 cell lines.

This study demonstrates the importance of obtaining our own expression results of OPG, RANKL, RANK, TRAIL, TRAIL-R (R1, R2, R3 and R4), SDF-1 and CXCR4 in cultures from the human BC cell lines MDAMB-231 and MCF-7 in different culture conditions. Taking these findings together with those previously 
obtained, allows us to understand some of the factors and mechanisms triggered prior to the appearance of bone metastasis and during the interactions between tumor cells, MSCs from BM and blood components in greater detail. It will be of interest to study simultaneously these molecules in tumor biopsies as well as in tumor epithelial cells isolated from BC patients. They may be useful in identifying patients with bone risk, and thus, they may improve decision related to the different treatments to combat cancer progression.

Finally, despite the advances in knowledge about these molecules, many questions remain unresolved, particularly regarding the conflicting roles of OPG in bone metastasis and the possible use of OPG as a potential therapeutic factor for tumors that produce metastases in $\mathrm{BM}$ and bone. In conclusion, MCF-7 and MDA-MB-231 cell lines not only released OPG but also expressed RANKL, TRAIL and SDF-1. The majority of these cells also expressed RANK, CXCR4 and TRAIL-R. Since these ligands and their receptors are involved in the regulation of breast tumor progression, the simultaneous assessment of these molecules in tumor biopsies of $\mathrm{BC}$ patients, particularly in the early clinical pathological stage, could be useful in identifying patients with more aggressive tumors that are also at risk of bone metastasis, which may thus improve the available options for therapeutic intervention.

\section{Methods}

\section{Breast cancer cell lines}

The MDA-MB-231 and MCF-7 lines were maintained in DMEM/F12 with $100 \mathrm{IU} / \mathrm{ml}$ penicillin-G, $100 \mu \mathrm{g} / \mathrm{ml}$ streptomycin sulfate, $25 \mu \mathrm{g} / \mathrm{ml}$ amphotericin B, $2 \mathrm{mM} \mathrm{L-}$ glutamine (supplemented DMEM/F12) (Gibco/Life Technologies, Grand Island, NY, USA) and $10 \%$ fetal bovine serum (FBS; Natocor, Argentina), complete DMEM/F12, at $37{ }^{\circ} \mathrm{C}$ under $5 \% \mathrm{CO}_{2}$. In the case of the MCF-7 line, $2 \mu \mathrm{g} / \mathrm{ml}$ of humanized porcine insulin (Laboratories Beta, Argentina) was added. The medium was changed every 3-4 days. The cells were used up to passage 4.

To better compare the expression of OPG, RANKL, TRAIL, SDF-1 and their receptors (RANK, TRAIL-R1-4 and CXCR4), both BC cell lines were grown under two culture conditions: A) traditional and B) adherence, arrest and post-stimulation.

\section{Traditional culture conditions (A)}

The BC cell lines $\left(18 \times 10^{3}\right.$ or $50 \times 10^{3}$ cells $\left./ \mathrm{cm}^{2}\right)$ were cultured in complete DMEM/F12 for 24, 48, 72 or $96 \mathrm{~h}$. Then, the CM were harvested from $\mathrm{BC}$ cell lines on days 1 to 4 (D1, D2, D3 and D4), centrifuged at $300 \mathrm{~g}$ for $15 \mathrm{~min}$ and stored at $-20^{\circ} \mathrm{C}$ until use. This experiment was repeated four times.

\section{Adherence, arrest and post-stimulation culture conditions (B)}

The BC cell lines $\left(18 \times 10^{3}\right.$ cells $\left./ \mathrm{cm}^{2}\right)$ were cultured in complete DMEM/F12 without phenol red (D2906, Sigma, St. Louis, MO, USA) for $24 \mathrm{~h}$ (adherence) and then with supplemented DMEM/F12 without phenol red, insulin and FBS for an additional $48 \mathrm{~h}$ (arrest). Finally, the cells were cultured with complete DMEM/F12 for $48 \mathrm{~h}$ (stimulus). The CM from the arrest and poststimulation culture conditions were harvested, centrifuged at $300 \mathrm{~g}$ for $15 \mathrm{~min}$ and stored at $-20^{\circ} \mathrm{C}$ until use. The experiment was repeated four times.

\section{ELISA assays}

The CM from both culture conditions ( $\mathbf{A}$ and $\mathbf{B})$ were used to evaluate OPG, RANKL, TRAIL and SDF-1 levels via ELISA methodology. Cells from both culture conditions (A and $\mathbf{B}$ ) were harvested using a solution of trypsin-EDTA (0.05-0.02 \% in PBS, Gibco) with the purpose of evaluating the number of total cells/culture; the levels of these factors were then expressed per $1 \times 10^{6}$ cells.

OPG, RANKL and SDF-1 levels were measured in the CM using commercial ELISA kits (DY805, R\&D, Minneapolis, MN, USA; RHF740CKC, Antigenix America, Huntington Station, NY, USA; and DY350, R\&D, respectively). TRAIL was measured using an ELISA kit developed in our laboratory. This procedure was performed according to the manufacturer's recommendations for human TRAIL/TNFSF10 (DY375, R\&D) but using antihuman TRAIL (MAB3751, R\&D) as capture Ab; recombinant human TRAIL (rhTRAIL, 375-TL, R\&D, at 31.25 to $2,000 \mathrm{pg} / \mathrm{ml}$ ) to produce a standard curve; and antihuman TRAIL (BAF375, R\&D) as a detection Ab together with streptavidin-peroxidase (S5512, Sigma).

The enzyme activity was revealed using a 3,3',5,5' -Tetramethylbenzidine (TMB) substrate (Sigma), and it was abolished using $1 \mathrm{~N} \mathrm{HCl}$ (Merck). The absorbance was read at $450 \mathrm{~nm}$ using a microplate reader set (BIO-RAD, Hercules, CA, USA). Supplemented DMEM-F12 with $10 \%$ FBS (D0) was used as a control, and its value was eliminated as a test target. Samples were assayed in triplicate. The $\mathrm{CM}$ were assayed from four experiments run under both culture conditions (A and $\mathbf{B}$ ). The levels of the OPG, RANKL, TRAIL and SDF-1 proteins from the ELISA analyses were calculated in $\mathrm{pg} / \mathrm{ml} / 1 \times 10^{6}$ cells.

\section{Immunofluorescence assays}

The $\mathrm{BC}$ cells from both culture conditions (A and $\mathbf{B}$ ) were used to evaluate the expression of OPG, RANKL and TRAIL via immunofluorescence. The experiment was repeated four times for each culture condition.

$\mathrm{BC}$ cells $\left(18 \times 10^{3}\right.$ cells/well/130 $\left.\mu \mathrm{l}\right)$ were grown on multi-test slides (096041805, MP Biomedicals, Santa 
Ana, CA, USA) during both culture conditions (A and B). Then, the BC cells were washed with PBS and fixed with $4 \%$ paraformaldehyde for $30 \mathrm{~min}$. After blocking in PBS-1 \% BSA, the cells were incubated with the following primary human Abs: anti-OPG (AB21259, Chemicon, Billerica, MA, USA), anti-RANKL (MAB626, R\&D) and anti-TRAIL (MAB687, R\&D). The presence of OPG was visualized using FITC-labeled goat anti-rabbit IgG $(\mathrm{H}+\mathrm{L})$ (FI-1000, Vector Lab), and the presence of RANKL and TRAIL was visualized using Cy3-labeled goat anti-mouse IgG $(\mathrm{H}+\mathrm{L})$ (111-165-146, Jackson). Finally, mounting media with DAPI was used to visualize nuclei (Vectashield solution, H-1500, Vector Lab). Confocal microscopy analyses were performed using a Nikon C1 laser-scanning confocal microscope (Plan Apo 40x/ 0.95). The acquisition software used was MetaMorph image analysis software.

$\mathrm{BC}$ cells were also incubated without primary Abs; with irrelevant IgG1 [mouse IgG1 isotype (X0931, Dako, Carpinteria, CA, USA)]; with normal mouse Igs (086599, Zymed, San Francisco, CA, USA); or with normal rabbit Igs (X0936, Dako) as a negative isotype control. Each sample was assayed in quadruplicate.

\section{Immunocytochemistry}

The BC cells from both culture conditions (A and B) were used to evaluate the expression of RANKL, RANK, TRAIL-R1-4, SDF-1 and CXCR4 via immunocytochemistry assays. The experiment was repeated four times for each culture condition.

BC cells $\left(18 \times 10^{3}\right.$ cells/well/130 $\left.\mu \mathrm{l}\right)$ were fixed in $4 \%$ paraformaldehyde, except for cells that were used to evaluate the expression of mRANKL and mRANK. After blocking endogenous peroxidase activity and nonspecific sites (PBS-BSA $1 \%$ ), the BC cells were incubated with the following primary human Abs: anti-RANKL (AB1862, Chemicon), anti-RANK (MAB683, R\&D), antiTRAIL-R1 (AF347, R\&D), anti-TRAIL-R2 (MAB6311, R\&D), anti-TRAIL-R3 (MAB6301, R\&D), anti-TRAIL-R4 (AF633, R\&D), anti-SDF-1 (MAB350, R\&D), anti-CXCR4 (MAB172, R\&D) and anti-AE1AE3 as a positive control (IR053, Dako). According to the manufacturer's recommendations, a peroxidase-based immunocytochemistry staining method (K0690, Dako) was used for primary Ab detection, and a 3,3'-diaminobenzidine tetrahydrochloride (DAB) substrate system (K3468, Dako) was used as the chromogen.

Negative controls without primary Abs; with an irrelevant $\mathrm{Ab}$ as a negative isotype control [mouse IgG1 isotype (X0931, Dako)]; with normal mouse Igs (08-6599, Zymed); with normal goat IgG (AB-108-C, R\&D); or with normal rabbit Igs (X0936, Dako) were used to assess non-specific staining. Each sample was assayed in quadruplicate.

\section{Statistical analysis}

Data obtained from ELISA were expressed as $\bar{X} \pm$ standard error (SE) $\mathrm{pg} / \mathrm{ml} / 1 \times 10^{6}$ cells. The statistical significance of the differences in the measured values among groups was evaluated by one-way analysis of variance (ANOVA) followed by a Bonferroni post hoc test. For individual comparisons, an independent unpaired t-test with Welch's correction was used. A difference was considered statistically significant if $\mathrm{p}<0.05$.

\section{Abbreviations}

Ab: Antibody; AE1AE3: Anti-cytokeratin monoclonal antibodies; ANOVA: Analysis of variance; BC: Breast cancer; BM: Bone marrow; CM: Conditioned media; CXCR4: C-X-C chemokine receptor type 4; C: Cytoplasmatic; Day: D; Dc: Decoy; ER: Estrogen-R; FBS: Fetal bovine serum; HER-2: Epidermal growth factor receptor 2; M: Membrane; M-CSFR: Macrophage colony stimulating factor receptor; M-CSF: M-CSF-R ligand; MSC: Mesenchymalstem cells; OPG: Osteoprotegerin; PG: Proteoglycans; R: Receptor; RANK: Activator of nuclear factor kappaB; RANKL: RANK ligand; Rh: Recombinant human; SC: Stem cells; SDF-1: Stromal cell-derived factor 1 SE: Standard error; TNF: Tumor necrosis factor; TRAIL: TNF-related apoptosisinducing ligand.

\section{Competing interests}

The authors declare that they have no competing financial interests.

\section{Acknowledgments}

This research was supported by grants from the National Agency of Scientific and Technological Promotion (FONCYT PICT 2006-01915), CONICET (PIP 2011/2013) and Roemmers Foundation (2009-2011), Buenos Aires, Argentina.

\section{Author details}

'Laboratorio de Inmuno-Hematología, Instituto de Biología y Medicina Experimental (IBYME), Buenos Aires, Argentina. ${ }^{2}$ Consejo Nacional de Investigaciones, Científicas y Técnicas (CONICET), Buenos Aires, Argentina. ${ }^{3}$ Agencia Nacional de Promoción Científica y Tecnológica, Buenos Aires, Argentina. ${ }^{4}$ Present address: Vuelta de Obligado 2490, CP 1428, Buenos Aires, Argentina.

\section{Authors' contributions}

VL has contributed to the conception and design of the study, performed the statistical analysis, interpretation of data and drafted the manuscript. VBFV participated in the design of the study, performed the statistical analysis, drafted and revised the article. LMM cultured the cell lines, drafted and revised the article. OJ cultured the cell lines and carried out the western blot assay. ANC participated in the design of the study and in the revision of the article as well as in the final approval of the version to be submitted. All authors read and approved the final version of the manuscript.

Received: 22 March 2012 Accepted: 18 June 2012

Published: 18 June 2012

\section{References}

1. Parkin DM, Bray F, Ferlay J, Pisani P: Estimating the world cancer burden: Globocan 2000. Int J Cancer 2001, 94:153-156.

2. Bhatia P, Sanders MM, Hansen MF: Expression of receptor activator of nuclear factor-kappaB is inversely correlated with metastatic phenotype in breast carcinoma. Clin Cancer Res 2005, 11:162-165.

3. Kakarala M, Wicha MS: Implications of the cancer stem-cell hypothesis for breast cancer prevention and therapy. J Clin Oncol 2008, 26:2813-2820. Review.

4. Patel SA, Heinrich AC, Reddy BY, Srinivas B, Heidaran N, Rameshwar P: Breast cancer biology: the multifaceted roles of mesenchymal stem cells. J Oncol 2008, 2008:425895.

5. Moharita AL, Taborga M, Corcoran KE, Bryan M, Patel PS, Rameshwar P: SDF1alpha regulation in breast cancer cells contacting bone marrow stroma is critical for normal hematopoiesis. Blood 2006, 108:3245-3252. 
6. Nicolin V, Narducci P: Soluble TRAIL could enhance bone destruction acting on Rank-ligand in estrogen-independent human breast cancer cell line MDA-MB-231. Acta Histochem 2010, 112:189-192.

7. Jones DH, Nakashima T, Sanchez OH, Kozieradzki I, Komarova SV, Sarosi I, Morony S, Rubin E, Sarao R, Hojilla CV, Komnenovic V, Kong YY, Schreiber M, Dixon SJ, Sims SM, Khokha R, Wada T, Penninger JM: Regulation of cancer cell migration and bone metastasis by RANKL. Nature 2006, 440:692-696.

8. Lamoureux F, Moriceau G, Picarda G, Rousseau J, Trichet V, Rédini F: Regulation of osteoprotegerin pro- or anti-tumoral activity by bone tumor microenvironment. Biochim Biophys Acta 2010, 1805:17-24. Review.

9. Labrinidis A, Liapis V, le Thai M, Atkins GJ, Vincent C, Hay S, Sims NA, Zannettino AC, Findlay DM, Evdokiou A: Does Apo2L/TRAIL play any physiologic role in osteoclastogenesis?. Blood 2008, 111:5411-5412.

10. Thai le M, Labrinidis A, Hay S, Liapis V, Bouralexis S, Welldon K, Coventry BJ, Findlay DM, Evdokiou A: Apo2l/tumor necrosis factor-related apoptosisinducing ligand prevents breast cancer-induced bone destruction in a mouse model. Cancer Res 2006, 66:5363-5370.

11. Zauli G, Melloni E, Capitani S, Secchiero P: Role of full-length osteoprotegerin in tumor cell biology. Cell Mol Life Sci 2009, 66:841-851. Review.

12. Fili S, Karalaki M, Schaller B: Mechanism of bone metastasis: the role of osteoprotegerin and of the host-tissue microenvironment-related survival factors. Cancer Lett 2009, 283(Fili S, Karalaki M, Schaller B):10-19. Review.

13. Tanaka $H$, Mine $T$, Ogasa $H$, Taguchi $T$, Liang $C T$ : Expression of RANKL/OPG during bone remodeling in vivo. Biochem Biophys Res Commun 2011 411:690-694.

14. Buckle $\mathrm{CH}$, Neville-Webbe HL, Croucher PI, Lawson MA: Targeting RANK/ RANKL in the treatment of solid tumours and myeloma. Curr Pharm Des 2010, 16:1272-1283. Review.

15. Stanisławowski M, Kmieć Z: The participation of RANK, RANKL and OPG in tumor osteolysis. Postepy Hig Med Dosw (Online) 2009, 63:234-241. Polish.

16. Canon JR, Roudier M, Bryant R, Morony S, Stolina M, Kostenuik PJ, Dougall WC: Inhibition of RANKL blocks skeletal tumor progression and improves survival in a mouse model of breast cancer bone metastasis. Clin Exp Metastasis 2008, 25:119-129.

17. Holland PM, Miller R, Jones J, Douangpanya H, Piasecki J, Roudier M, Dougall WC: Combined therapy with the RANKL inhibitor RANK-Fc and rhApo2L/ TRAIL/dulanermin reduces bone lesions and skeletal tumor burden in a model of breast cancer skeletal metastasis. Cancer Biol Ther 2010, 9:539-550.

18. Zinonos I, Labrinidis A, Lee $M$, Liapis $V$, Hay S, Ponomarev V, Diamond P, Findlay DM, Zannettino AC, Evdokiou A: Anticancer efficacy of Apo2L/ TRAIL is retained in the presence of high and biologically active concentrations of osteoprotegerin in vivo. J Bone Miner Res 2011, 26:630-643

19. LeBlanc HN, Ashkenazi A: Apo2L/TRAIL and its death and decoy receptors. Cell Death Differ 2003, 10:66-75. Review.

20. Takeda K, Stagg J, Yagita H, Okumura K, Smyth MJ: Targeting death-inducing receptors in cancer therapy. Oncogene 2007, 26:3745-3757. Review.

21. Yagita H, Takeda K, Hayakawa Y, Smyth MJ, Okumura K: TRAIL and its receptors as targets for cancer therapy. Cancer Sci 2004, 95:777. Review.

22. Ashkenazi A, Holland P, Eckhardt SG: Ligand-based targeting of apoptosis in cancer: the potential of recombinant human apoptosis ligand 2/Tumor necrosis factor-related apoptosis-inducing ligand (rhApo2L/TRAIL). J Clin Oncol 2008, 26:3621-3630. Review.

23. Kruyt FA: TRAIL and cancer therapy. Cancer Lett 2008, 263:14-25. Review.

24. Zhang $Y$, Zhang B: TRAIL resistance of breast cancer cells is associated with constitutive endocytosis of death receptors 4 and 5. Mol Cancer Res 2008, 6:1861-1871.

25. Cui DD, Huang Y, Mao SH, Chen SC, Qiu M, Ji LL, Yi C: Synergistic antitumor effect of TRAIL and adriamycin on the human breast cancer cell line MCF-7. Braz J Med Biol Res 2009, 42:854-862.

26. Lacour S, Hammann A, Wotawa A, Corcos L, Solary E, Dimanche-Boitrel MT Anticancer agents sensitize tumor cells to tumor necrosis factor-related apoptosis-inducing ligand-mediated caspase- 8 activation and apoptosis. Cancer Res 2001, 61:1645-1651.

27. Furusato B, Mohamed A, Uhlén M, Rhim JS: CXCR4 and cancer. Pathol Int 2010, 60:497-505. Review.

28. Huang M, Li Y, Zhang H, Nan F: Breast cancer stromal fibroblasts promote the generation of CD44 + CD24- cells through SDF-1/CXCR4 interaction. J Exp Clin Cancer Res 2010, 29:80.
29. Kobayashi T, Tsuda H, Moriya T, Yamasaki T, Kikuchi R, Ueda S, Omata J, Yamamoto J, Matsubara O: Expression pattern of stromal cell-derived factor-1 chemokine in invasive breast cancer is correlated with estrogen receptor status and patient prognosis. Breast Cancer Res Treat 2010, 123:733-745.

30. Müller A, Homey B, Soto H, Ge N, Catron D, Buchanan ME, McClanahan T, Murphy E, Yuan W, Wagner SN, Barrera JL, Mohar A, Verástegui E, Zlotnik A: Involvement of chemokine receptors in breast cancer metastasis. Nature 2001, 410:50-56

31. Salvucci O, Yao L, Villalba S, Sajewicz A, Pittaluga S, Tosato G: Regulation of endothelial cell branching morphogenesis by endogenous chemokine stromal-derived factor-1. Blood 2002, 99:2703-2711.

32. Wang Z, Ma Q, Liu Q, Yu H, Zhao L, Shen S, Yao J: Blockade of SDF-1 /CXCR4 signalling inhibits pancreatic cancer progression in vitro via inactivation of canonical Wnt pathway. Br J Cancer 2008, 99:1695-1703.

33. Balkwill F: Cancer and the chemokine network. Nat Rev Cancer 2004, 4:540-550. Review.

34. Smith MC, Luker KE, Garbow JR, Prior JL, Jackson E, Piwnica-Worms D, Luker GD: CXCR4 regulates growth of both primary and metastatic breast cancer. Cancer Res 2004, 64:8604-8612.

35. Rhodes LV, Short SP, Neel NF, Salvo VA, Zhu Y, Elliott S, Wei Y, Yu D, Sun M, Muir SE, Fonseca JP, Bratton MR, Segar C, Tilghman SL, Sobolik-Delmaire T, Horton LW, Zaja-Milatovic S, Collins-Burow BM, Wadsworth S, Beckman BS, Wood CE, Fuqua SA, Nephew KP, Dent P, Worthylake RA, Curiel TJ, Hung MC, Richmond A, Burow ME: Cytokine receptor CXCR4 mediates estrogen-independent tumorigenesis, metastasis, and resistance to endocrine therapy in human breast cancer. Cancer Res 2011, 71:603-613.

36. Kang H, Watkins G, Parr C, Douglas-Jones A, Mansel RE, Jiang WG: Stromal cell derived factor-1: its influence on invasiveness and migration of breast cancer cells in vitro, and its association with prognosis and survival in human breast cancer. Breast Cancer Res 2005, 7:R402-410.

37. Lapteva N, Yang AG, Sanders DE, Strube RW, Chen SY: CXCR4 knockdown by small interfering RNA abrogates breast tumor growth in vivo. Cancer Gene Ther 2005, 12:84-89.

38. Schrader AJ, Lechner O, Templin M, Dittmar KE, Machtens S, Mengel M, Probst-Kepper M, Franzke A, Wollensak T, Gatzlaff P, Atzpodien J, Buer J, Lauber J: CXCR4/CXCL12 expression and signalling in kidney cancer. $\mathrm{Br}$ J Cancer 2002, 86:1250-1256.

39. Corcoran KE, Trzaska KA, Fernandes H, Bryan M, Taborga M, Srinivas V, Packman K, Patel PS, Rameshwar P: Mesenchymal stem cells in early entry of breast cancer into bone marrow. PLoS One 2008, 3:e2563.

40. Honczarenko M, Le Y, Swierkowski M, Ghiran I, Glodek AM, Silberstein LE: Human bone marrow stromal cells express a distinct set of biologically functional chemokine receptors. Stem Cells 2006, 24:1030-1041.

41. Juarez J, Bendall L, Bradstock K: Chemokines and their receptors as therapeutic targets: the role of the SDF-1/CXCR4 axis. Curr Pharm Des 2004, 10:1245-1259. Review.

42. Coleman RE: Metastatic bone disease: clinical features, pathophysiology and treatment strategies. Cancer Treat Rev 2001, 27:165-176. Review.

43. Cross SS, Harrison RF, Balasubramanian SP, Lippitt JM, Evans CA, Reed MW, Holen I: Expression of receptor activator of nuclear factor kappabeta ligand (RANKL) and tumour necrosis factor related, apoptosis inducing ligand (TRAIL) in breast cancer, and their relations with osteoprotegerin, oestrogen receptor, and clinicopathological variables. J Clin Pathol 2006, 59:716-720.

44. Neville-Webbe HL, Cross NA, Eaton CL, Nyambo R, Evans CA, Coleman RE, Holen I: Osteoprotegerin (OPG) produced by bone marrow stromal cells protects breast cancer cells from TRAIL-induced apoptosis. Breast Cancer Res Treat 2004, 86:269-279.

45. Van Poznak C, Cross SS, Saggese M, Hudis C, Panageas KS, Norton L, Coleman RE, Holen I: Expression of osteoprotegerin (OPG), TNF related apoptosis inducing ligand (TRAIL), and receptor activator of nuclear factor kappaB ligand (RANKL) in human breast tumours. J Clin Pathol 2006, 59:56-63.

46. Hofbauer LC, Rachner T, Singh SK: Fatal attraction: why breast cancer cells home to bone. Breast Cancer Res 2008, 10:101

47. Santini D, Schiavon G, Vincenzi B, Gaeta L, Pantano F, Russo A, Ortega C, Porta C, Galluzzo S, Armento G, La Verde N, Caroti C, Treilleux I, Ruggiero A, Perrone G, Addeo R, Clezardin P, Muda AO, Tonini G: Receptor activator of NF-kB (RANK) expression in primary tumors associates with bone metastasis occurrence in breast cancer patients. PLoS One 2011, 6:e19234. 
48. Brunetti G, Oranger A, Mori G, Sardone F, Pignataro P, Coricciati M, Napoli N, Rizzi R, Liso V, Grassi FR, Grano M, Colucci S: TRAIL effect on osteoclast formation in physiological and pathological conditions. Front Biosci (Elite Ed) 2011, 3:1154-1161.

49. Colucci S, Brunetti G, Cantatore FP, Oranger A, Mori G, Pignataro P, Tamma R, Grassi FR, Zallone A, Grano M: The death receptor DR5 is involved in TRAILmediated human osteoclast apoptosis. Apoptosis 2007, 12:1623-1632.

50. Romieu-Mourez R, François M, Boivin MN, Bouchentouf M, Spaner DE, Galipeau J: Cytokine modulation of TLR expression and activation in mesenchymal stromal cells leads to a proinflammatory phenotype. J Immunol 2009, 182:7963-7973.

51. Fernández Vallone V, Choi H, Martinez LM, Labovsky V, Batagelj E, Dimase F, Feldman L, Bordenave RH, Chasseing NA: Osteoclastogenesis process in bone marrow of untreated advanced breast cancer patients [abstract]. Program and Proceedings 2010, 105:B34.

52. Martinez LM, Labovsky V: Fernández Vallone VB, Bordenave RH, Feldman L, Chasseing NA: MCS and breast tumor cells [abstract]. Program and Proceedings 2010, 86:A114.

53. Velasco CR, Colliec-Jouault S, Redini F, Heymann D, Padrines M: Proteoglycans on bone tumor development. Drug Discovery Today 2010, 15:553-560. Review.

54. Baud'huin M, Ruiz-Velasco C, Jego G, Charrier C, Gasiunas N, Gallagher J, Maillasson M, Naggi A, Padrines M, Redini F, Duplomb L, Heymann D: Glycosaminoglycans inhibit the adherence and the spreading of osteoclasts and their precursors: role in osteoclastogenesis and bone resorption. Eur I Cell Biol 2011, 90:49-57.

55. Holen I, Shipman CM: Role of osteoprotegerin (OPG) in cancer. Clin Sci (Lond) 2006, 110:279-291. Review.

56. Kapoor P, Suva $L$, Welch DR, Donahue HJ: Osteoprotegrin and the bone homing and colonization potential of breast cancer cells. J Cell Biochem 2008, 103:30-41.

57. Brown JM, Zhang J, Keller ET: Opg, RANKI, and RANK in cancer metastasis: expression and regulation. Cancer Treat Res 2004, Review:149-172. Review.

58. Patsialou A, Wyckoff J, Wang Y, Goswami S, Stanley ER, Condeelis JS: Invasion of human breast cancer cells in vivo requires both paracrine and autocrine loops involving the colony-stimulating factor-1 receptor. Cancer Res 2009, 69:9498-9506.

59. Ibrahim T, Sacanna E, Gaudio M, Mercatali L, Scarpi E, Zoli W, Serra P, Ricci R, Serra L, Kang Y, Amadori D: Role of RANK, RANKL, OPG, and CXCR4 Tissue Markers in Predicting Bone Metastases in Breast Cancer Patients. Clin Breast Cancer 2011, 11:369-375.

60. Ponte AL, Marais E, Gallay N, Langonné A, Delorme B, Hérault O, Charbord $\mathrm{P}$, Domenech J: The in vitro migration capacity of human bone marrow mesenchymal stem cells: comparison of chemokine and growth factor chemotactic activities. Stem Cells 2007, 25:1737-1745.

61. Sanliogliu AD, Korcum AF, Pestereli E, Erdogan G, Karaveli S, Savas B, Griffith TS, Sanlioglu S: TRAIL death receptor-4 expression positively correlates with the tumor grade in breast cancer patients with invasive ductal carcinoma. Int J Radiat Oncol Biol Phys 2007, 69:716-723.

62. Kimberley FC, Screaton GR: Following a TRAIL: update on a ligand and its five receptors. Cell Res 2004, 14:359-372. Review.

63. Mérino D, Lalaoui N, Morizot A, Schneider P, Solary E, Micheau O: Differential inhibition of TRAIL-mediated DR5-DISC formation by decoy receptors 1 and 2. Mol Cell Biol 2006, 26:7046-7055.

\section{Submit your next manuscript to BioMed Central and take full advantage of:}

- Convenient online submission

- Thorough peer review

- No space constraints or color figure charges

- Immediate publication on acceptance

- Inclusion in PubMed, CAS, Scopus and Google Scholar

- Research which is freely available for redistribution

Submit your manuscript at www.biomedcentral.com/submit
Ciomed Central 